\title{
PENINGKATAN KEMAMPUAN PENGGUNAAN MEDIA PEMBELAJARAN BERBASIS IT BAGI KELOMPOK GURU MATEMATIKA DAN IPA SMP DI KABUPATEN BANDUNG JAWA BARAT
}

\author{
Neneng Nuryati ${ }^{1}$, Sri Suratmi ${ }^{1}$, Siti S Purwaningsih ${ }^{1}$, Euis Sartika ${ }^{1}$, Ratu Fenny \\ Muldianni ${ }^{1}$ \\ ${ }^{1}$ UP MKU Politeknik Negeri Bandung
}

Email: neng nuryati@yahoo.com, srisuratmi polban@yahoo.com, sitisamsiyahpurwaningsih@yahoo.co.id, euissartika sartika@yahoo.com, fen238@yahoo.com

\begin{abstract}
Abstrak
Penggunanan sarana pembelajaran untuk meningkatkan proses belajar mengajar siswa, menjadi strategi yang paling efektif. Salah satu sarana pembelajaran berbasis IT yang digunakan adalah pemanfatan komputer. Guru dapat menjelaskan materi pembelajaran kepada siswa dengan lebih mudah, menarik, dan efektif. Kegiatan pengabdian kepada masyarakat melalui pelatihan pemanfatan komputer ini bertujuan untuk meningkatkan kompetensi para guru SMP pada bidang IT di lingkungan kelompok Musyawarah Guru Mata Pelajaran (MGMP) Matematika dan IPA Gugus 04 yang bertindak sebagai mitra kegiatan pengabdian. Materi yang diberikan adalah Microsoft Office yang meliputi Microsoft Word, Microsoft Excel, dan Microsoft Power Point. Pelaksanaan dimulai dengan tahap evaluasi awal yaitu identifikasi kemampuan awal para peserta melalui pretest mengenai materi yang akan diberikan. Metode pelaksanaan dilakukan dengan ceramah mengenai teori dasar pengetikan, praktek penggunaan Microsoft Word, Microsoft Excel, dan Microsoft Power Point, dan menginterpretasikan output dari hasil tampilan. Sebagai evaluasi, peserta diharuskan membuat tugas mandiri yakni membuat bahan ajar yang disesuaikan materi yang diampu dengan menggunakan ketiga software tersebut dan presentasi. Tahap akhir evaluasi peserta adalah postest. Hasil menunjukkan terdapat kenaikan pengetahuan peserta sebesar 27,5\%. Secara kualitatif, hasil kuesioner menunjukkan bahwa seluruh peserta pelatihan memberikan respon positif terhadap seluruh kegiatan PKM.
\end{abstract}

Kata kunci: Media pembelajaran, Pelatihan Microsoft office, IT

\section{PENDAHULUAN}

Kualitas sumber daya manusia dicerminkan oleh kualitas pendidikan dan merupakan aset utama dalam pembangunan. Fakta menunjukkan bahwa kualitas pendidikan di Indonesia masih rendah pada peringkat dunia. Berdasarkan Human Development Index (HDI) dari UNP (Kusumah, 
DIFUSI

Volume 2, No.1 Januari 2019

2008), Indonesia menempati urutan ke110, peringkat terendah dibandingkan negara lainnya di Asia, negara Asia tersebut adalah Vietnam peringkat 109, China urutan 96, peringkat 77 diduduki oleh Filipina (77), Thailand menduduki urutan ke-70, Malaysia peringkat ke-59, peringkat ke-32 di diduduki Brunai Darussalam, Singapura menempati urutan ke-25, dan Jepang menduduki urutan ke-9. International Achievement Education (IEA) juga menyatakan bahwa kemampuan siswa SMP Indonesia untuk mata pelajaran matematika menduduki urutan ke-39 dari 42 negara peserta; kemampuan siswa SMP untuk mata pelajaran IPA menduduki peringkat ke-40 dari 42 negara peserta (Kusumah, 2008). Sementara di Indonesia sendiri penetapan nilai kelulusan UN yang hanya 5,5 masih banyak yang menentang. Tantangan ini tidak hanya berasal dari orang tua atau siswa namun juga dari guru sebagai pakar pendidikan. Alasannya nilai itu terlalu tinggi untuk siswa, siswa belum mampu untuk mencapai nilai UN 5,5.

Untuk itulah, melalui kegiatan PKM ini, Polban sebagai salah satu institusi pendidikan turut serta mengambil peran dalam mengatasi permasalahan ini. Tujuan PKM adalah meningkatkan kemampuan para guru SMP Matematika dan IPA dalam penggunaan IT sebagai salah satu media pembelajaran siswa. Lokasi kegiatan pengabdian masyarakat yang dilaksanakan di wilayah Kabupaten Bandung yakni MGMP Gugus 04 yang meliputi Kecamatan Margahayu, Marga Asih, dan Kecamatan Katapang. Jarak dari Polban ke lokasi kegiatan berkisar $22 \mathrm{~km}$ ke arah Bandung selatan (peta terlampir). Alasan penentuan lokasi kegiatan pengabdian masyarakat di Gugus tadi antara lain :

1. Jumlah SMP Negeri sebanyak 7 buah dan jumlah SMP Swasta sebanyak 15 buah.

2. Banyaknya kelas untuk SMP Negeri masing-masing 30 kelas (ketentuan dinas pendidikan setempat), sedangkan untuk SMP Swasta sangat bergantung daya tampung sekolahnya, yaitu kisaran dari 9 kelas.

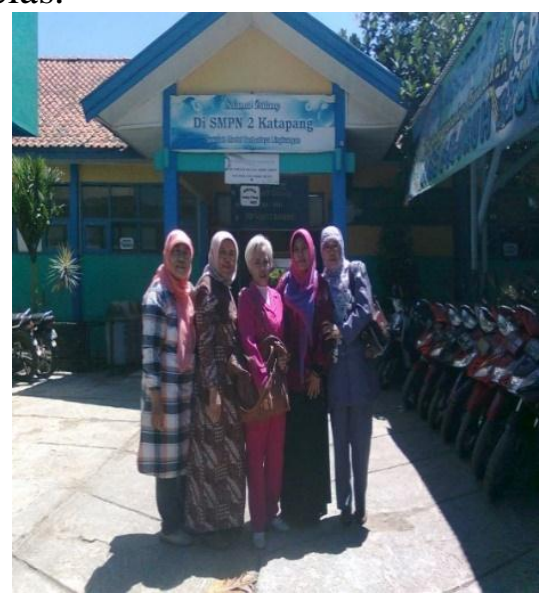

Gambar 1. Lokasi SMP Negeri II Katapang

3. Jumlah guru mata pelajaran Matematika di SMP Negeri rata-rata adalah 5 orang dengan status PNS bersertifikasi guru. Sedangkan guru mata pelajaran IPA Fisika rata-rata sebanyak 6 orang dengan status PNS bersertifikasi.

4. Jumlah guru mata pelajaran Matematika dan Fisiska di SMP Swasta rata-rata memiliki satu guru dengan status PNS bersertifikasi guru. Dan selebihnya menggunakan guru honorer atau guru tetap Yayasan.

5. Hasil UN di SMP gugus 04 masih relatif rendah, sebagai contoh nilai UN Di SMP Negeri II Katapang 
DIFUSI

Volume 2, No.1 Januari 2019

(foto gambar 2), untuk mata pelajaran Matematika mencapai nilai NEM rata-rata untuk tahun 2013 sebesar 4,3 nilai terbesar 9 dan terendah 1,75. Sedangkan untuk mata pelajaran IPA Fisika mempunyai NEM rata-rata untuk tahun 2013 sebesar 5 nilai terbesar 9,5 dan terendah 2,5.

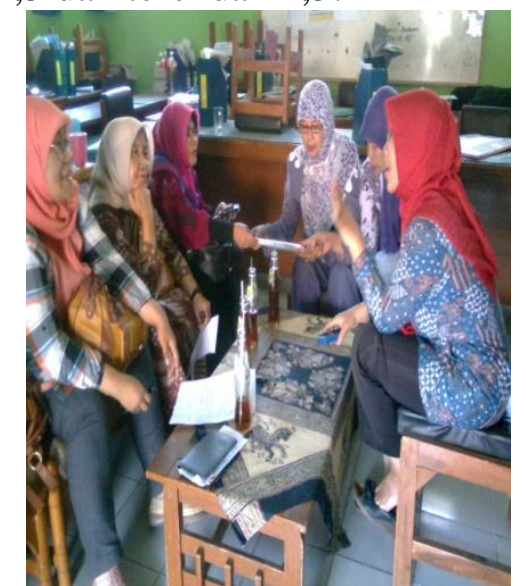

Gambar 2. Kegiatan Studi Pendahulun

Berdasarkan informasi tatap muka saat survey (foto gambar 2) dari MGMP Gugus 04, guru-guru tersebut baru sebagian kecil yang telah mendapat pelatihan pembelajaran berbantuan komputer. Ditambah dengan kondisi beban tugas para guru terutama di SMP Negeri menjadi lebih berat karena sebagian besar guru tersebut menjadi guru honorer di SMP pada gugus yang sama. Sehingga menciptakan kondisi yang serupa untuk kemampuan pembelajaran berbantuan komputernya. Ditambah lagi input siswa SMP di Gugus tersebut berasal dari golongan ekonomi menengah dan golongan tidak mampu, jadi masih terdapat siswa yang kehidupan keluarganya dibantu oleh program pemerintah untuk rakyat miskin bantuan langsung dalam bentuk uang nominal, ba), dan Antuan beras untuk rakyat miskin, dan jaminan asuransi Kesehatan Miskin (Askeskin) dan atau Jaminan Kesehatan Masyarakat (Jamkesmas).

Alasan lain penentuan lokasi kegiatan pengabdian masyarakat di Katapang adalah aspek tingkat kehidupan masyarakat terutama dari sisi ekonomi. Hal ini dapat dilihat dari para lulusan SMP di wilayah Gugus tersebut hanya $30 \%$ yang melanjutkan pendidikan ke jenjang lebih tinggi. Sebagian besar lulusan SMP di daerah Katapang tidak melanjutkan pendidikan melainkan menjadi buruh pabrik, untuk meningkatkan kesejahteraan keluarga.

Matematika dan IPA (Fisika) merupakan bidang studi yang menjadi momok menakutkan bagi siswa SMP. Sehingga banyak siswa yang menganggap sulit belajar matematika, akibatnya mereka menjauhi bahkan membenci mata pelajaran Matematika dan Fisika. Untuk menghilangkan kesan negatif tersebut, pengajar Matematika dan IPA Fisika harus pandai menentukan cara atau kemasan, sarana, dan alat pembelajaran yang tepat dan menarik disertai dengan contoh aplikasi, sehingga memudahkan siswa dalam memahami konsep. Kondisi ini diharapkan dapat merangsang siswa untuk lebih bersemangat dalam mengikuti mata pelajaran tersebut.

Salah satu penerapan teknologi pada dunia pendidikan adalah penggunaan komputer. Beberapa guru dalam Kelompok MGMP Matematika dan IPA SMP belum dapat mengoptimalkan penggunaan komputer tersebut terutama dalam kegiatan pembelajaran. Hal ini ditunjukkan dari hasil studi pendahuluan yang dilakukan ternyata persentasi pengajaran yang 
menggunakan komputer (laptop) sebagai pembelajaran kurang dari 20 persen.

Seorang guru profesional semestinya memahami secara mendalam materi yang diajarkannya, mampu mengajarkan secara jelas dan padat (efektif), waktu lebih singkat dan tepat (efisien), dan berkepribadian mantap. Menurut Syah dalam Sartika dkk (2012), kompetensi profesional guru dibagi ke dalam tiga aspek yaitu kompetensi kognitif (penguasaan pengetahuan kependidikan, penguasaan pengetahuan materi bidang studi yang diajarkan, dan kemampuan mentransfer pengetahuan kepada siswa agar dapat berjalan secara efektif dan efisien), kompetensi afektif (sikap dan perasaan diri yang berkaitan dengan profesi keguruan), kompetensi psikomotorik (kecakapan fisik umum dan khusus seperti ekspresi verbal dan non verbal). Menyikapi kondisi yang ada pada MGMP Matematika dan IPA Fisika di SMP mitra, sudah semestinya yang terjun di dunia pendidikan membantu meringankan dan mensejahterakan sistem pembelajaran dengan memanfaatkan kemajuan teknologi di bidang komputer dan informasi, antara lain manfaat dari komputer sebagai media bagi guru untuk menyampaikan materi pembelajarannya kepada peserta didik. Guru matematika dan fisika sangatlah cocok untuk menggunakan bantuan komputer dalam menyampaikan materi pembelajaran baik secara teoritis bahkan sangat memberikan pemahaman yang mudah untuk materi yang memerlukan eksperimen, demonstrasi dan simulasi. Dengan demikian proses pembelajaran menjadi efektif sehingga mutu hasil belajar meningkat. Seperti yang dikatakan Eggen dan Kauchak (1988:1, menekankan bahwa: Effective learning occurs when students are actively involved in organizing and finding relationships in the information. They encounter rather than being passive recipients of teacher-delivered bodies of knowledge. The activity results not only increased learning and retention of content but also in improved thinking skills.

Dengan melakukan pembelajaran melalui kegiatan eksperimen siswa akan mendapatkan peluang untuk meningkatkan keterampilan intelektual dan keterampilan motorik secara simultan.

Software biang IT yang digunakan dalam dunia pendidikan seperti komputer, kalkulator grafik, televisi dan lain sebagainya disebut sebagai Information Computer and Tecnologi (ICT). Penelitian sebelumnya menunjukkan bahwa sebagian besar siswa kesulitan dalam belajar matematika dan Fisika pada awalnya, dapat meningkatkan hasil belajarnya menjadi lebih baik menggunakan ICT dibandingkan siswa yang belajar secara konvensional atau tidak menggunakan ICT. Lima komponen utama yang menyebabkan teknologi dipilih untuk alat pedagogis dalam pembelajaran matematika, menurut Peressini dan Knut (Jiang, 2006) yaitu:

1. Teknologi dapat disetarakan sebagai management.

2. Teknologi dapat berperilaku sebagai alat komunikasi.

3. Teknologi dapat menjadi alat evaluasi. 
DIFUSI

Volume 2, No.1 Januari 2019

4. Teknologi dapat bersikap sebagai alat bantu untuk memotivasi.

5. Pemanfaatan teknologi memudahkan dalam memahami algoritma matematik siswa menjadi lebih baik, sehingga mampu meningkatkan keterampilan dalam memahami konsep dan problem solving. Berkaitan dengan kapasitas peningkatan kemampuan kognitif, IT memberi tawaran yang efektif bagi siswa untuk berkesempatan mengeksplorasi konsep-konsep matematika. Hal ini memberi kesempatan dalam menggali cara baru untuk merepresentasikan secara kompleks, dan membentuk model baru baru untuk siswa dan guru agar dapat memanipulasi objek-objek yang abstrak dengan secara manual.

Penelitian yang dilakukan oleh Muldiani dkk (2009), dapat ditunjukkan bahwa hasil pembelajaran menggunakan bantuan media komputer lebih baik dibandingkan dengan metode konvensional. Untuk itu Media pembelajaran Matematika dan IPA Fisika yang dapat mempermudah pemahaman konsep akan lebih mengenai sasaran apabila didukung oleh IPTEK yaktu dalam pembelajran. Diharapkan dengan menggunakan alat bantu komputer sebagai media pembelajran, nilai Matematika dan IPA Fisika dapat meningkat karena media komputer diharapkan bisa membantu dalam pembelajaran.

Dari latar belakang di atas, kami selaku pengajar Matematika dan Fisika ingin berpartisipasi dalam meningkatkan kemampuan para guru untuk meningkatkan nilai UN melalui pengabdian masyarakat yang diadakan oleh UPPM Polban. Pengabdian serupa pernah diberikan pada guru Matematika melalui MGMP yang berada di Kota Cimahi.

Berdasarkan kegiatan pengabdian tahun 2012, diperoleh informasi bahwa kemampuan awal penggunaan software Microsoft Office dan Software Windows plotting para pengajar Matematika Sekolah Menengah Pertama masih kurang. Padahal sebagian besar peserta pernah mengikuti pelatihan yang serupa. Tetapi karena tidak digunakan dalam proses pembelajaran sehari-hari maka sebagian guru tidak familiar dengan software tersebut. Ditambah lagi Kegiatan Pengabdian Masyarakat tersebut belum dilakukan evaluasi keseluruhan dalam bentuk studi komparatif dikarenakan keterbatasan waktu, dimana pada saat yang bersamaan para guru SMP dihadapkan pada kegiatan UAN. Maka dari itu untuk kegiatan Pengabdian Masyarakat yang akan dilaksanakan kali ini pada MGMP Matematika dan Fisika SMP mitra, evaluasinya akan dilengkapi analisis komparatif. Diharapkan dengan adanya hasil studi komparatif ini dapat menghasilkan kontribusi terhadap MGMP Matematika dan Fisika khususnya dan pihak Polban pada umumnya. Analisis komparatif dilakukan setelah seluruh rangkaian kegiatan pelatihan selesai dilakukan dan para guru Matematika dan Fisika telah mempraktekannya dalam kegiatan pembelajaran. Sehingga analisis komparatif direncanakan pada kesempatan kegiatan Pengabdian Masyarakat tahun berikutnya. 


\section{TARGET DAN LUARAN}

Kegiatan pengabdian kepada masyarakat mempunyai target untuk meningkatan penggunaan Ms Office pada kegiatan pembelajaran. Sebagai evalusi, dapat ditunjukkan bahwa nilai kemampuan akhir (post test) dibandingkan nilai kemampuan awal (pre test) meningkat dengan rata-rata peningkatan signifikan, untuk Ms Word 3.54 (22.89\%), Ms Excel 3.53 (32.96\%), dan Ms Power Point 14,44 $(26.92 \%)$.

Luaran kegiatan pengabdian dari pelaksana berupa modul-modul pelatihan dengan judul Peningkatan Media Pembelajaran Matematika dan IPA Fisika menggunakan Microsoft Word, Peningkatan Kompetensi Guru dalam Penggunaan Microsoft Excel, Peningkatan Media Pembelajaran dengan Menggunakan Microsoft Power Point dan contoh implementasi ketiga software tersebut berupa petunjuk eksperimen pembelajaran.

Luaran kegiatan pengabdian dari mitra kegiatan ditunjukkan oleh adanya umpan balik dari hasil penugasan mandiri berupa aplikasi dari ketiga software yang dikirim mitra melalui email kepada pelaksana.

\section{METODE PELAKSANAAN}

\footnotetext{
Sebagian besar kegiatan pengabdian masyarakat yang telah dilakukan berbentuk pelatihan atau workshop. Diharapkan Pelatihan ini secara tidak langsung dapat menyelesaikan permasalahan dalam komunitas kelompok Musyawarah Guru Mata Pelajaran (MGMP) dan atau membantu meningkatkan kesejahteraan berupa peningkatan kompetensi guru
}

dalam bentuk keterampilan mengajar dengan alat bantu komputer. Pelatihan telah berlangsung selama 42 jam ditambah dengan tugas kerja mandiri, dengan durasi selama tiga minggu, dalam satu minggu dua hari, yaitu Jumat dan Sabtu. Peserta diperkirakan sekitar 30-40 orang yang terdiri dari kelompok guru Matematika dan kelompok guru Fisika dari beberapa SMP Gugus 04 Kabupaten Bandung.

Adapun tahapan kegiatan ini adalah sebagai berikut.

1. Identifikasi Kemampuan Awal.

Pada kegiatan awal, peserta mendapat tes awal atau pretes yang mengandung beberapa pertanyaan yang mengandung tahap kemampuan awal materi pelatihan.

2. Distribusi Peserta dilakukan setelah mendapatkan dasar pelatihan secra bersama berdasarkan keilmuan (Matematika dan Fisika).

Peserta dibagi menjadi dua kelompok, kelompok Matematika dan kelompok Fisika untuk dibedakan materi pelatihan dalam dua kelas paralel.

3. Materi pelatihan dikelompokkan ke dalam dua materi, yakni materi umum berupa teori dasar yang memberi penguatan dasar untuk mata pelajaran Matematika dan Fisika, materi khusus berupa aplikasi dan penggunaan teori dasar pada materi pembelajaran. Pemberian materi berikut dengan aplikasi yang disesuaikan dengan mata pelajaran Matematika dan Fisika.

4. Evaluasi awal setiap materi pelatihan dilakukan pada saat akhir materi. Untuk setiap bagian masing- 
DIFUSI

Volume 2, No.1 Januari 2019

masing MS Word, MS Excel, MS Power Poin.

5. Nilai evaluasi awal dijadikan referensi untuk evaluasi akhir kegiatan.

6. Evaluasi final dilakukan setelah seluruh rangkaian kegiatan selesai dilakukan. Analisis statistika dilakukan pada nilai pretest dan nilai postest sehingga didapat representasi berupa studi komparatif yang dilakukan untuk evaluasi keseluruhan kegiatan pengabdian pada masyarakat.

Berikut adalah diagram Pelaksanaan Kegiatan Pelatihan Pengabdian Masyarakat (gambar 3).

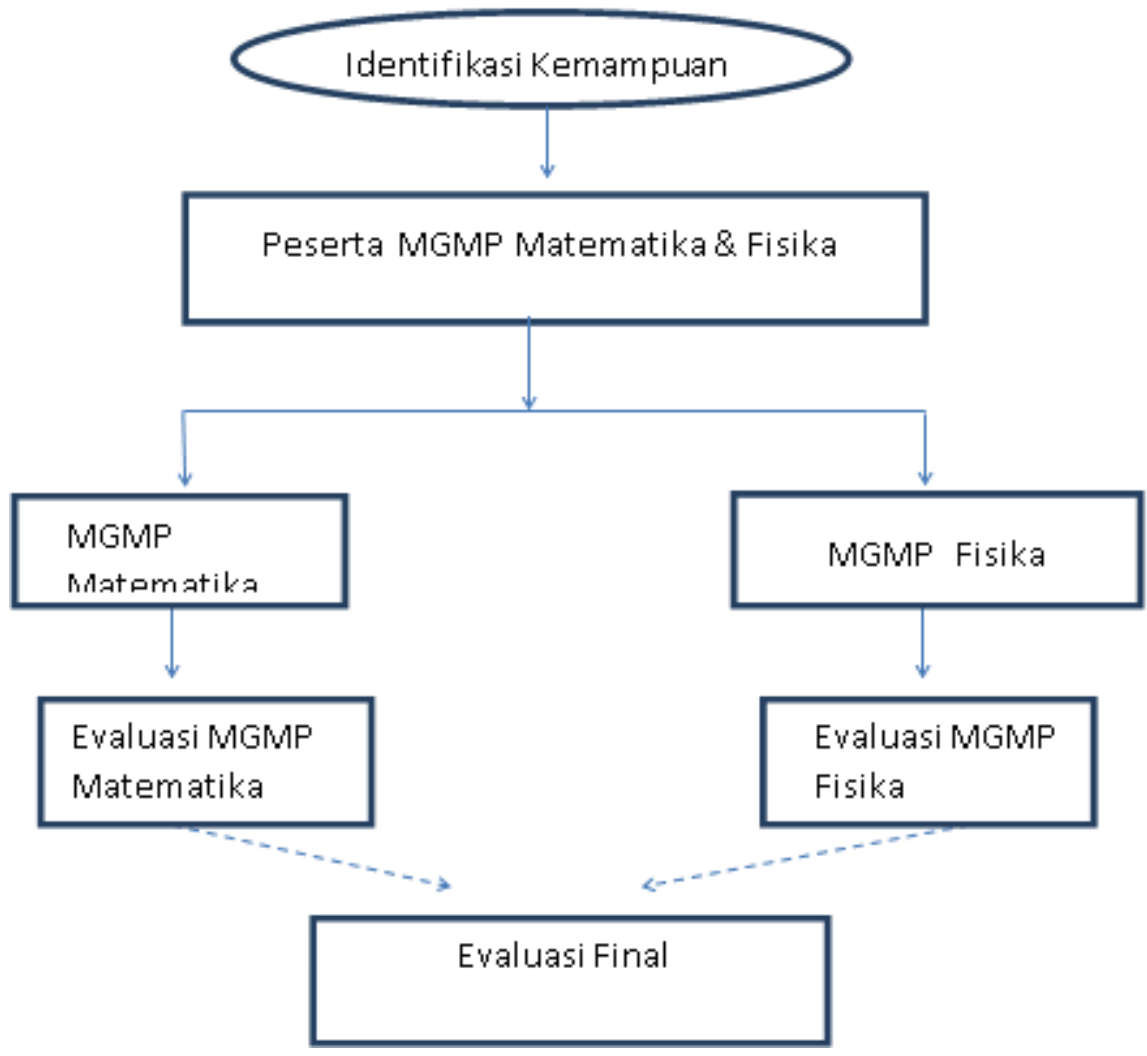

Gambar 3. Tahap-tahap pelaksanaan kegiatan

\section{HASIL YANG DICAPAI}

\section{Deskriptif Data}

Untuk mengidentifikasi keseluruhan data, digunakan analisis deskriptif sehingga diperoleh nilai terkecil, nilai terbesar, rata-rata, dan simpangan baku dari hasil evaluasi data pelatihan. Tabel berikut menyajikan analisis deskriptif dari data nilai pretest dan postest pelatihan MS Word dengan menggunakan program SPSS 13.00. 
DIFUSI

Volume 2, No.1 Januari 2019

Tabel 1 Deskriptif Data Pelatihan MS

Word

\begin{tabular}{|c|c|c|c|c|}
\hline $\begin{array}{c}\text { Varia } \\
\text { bel }\end{array}$ & $\begin{array}{c}\text { Minim } \\
\text { um }\end{array}$ & $\begin{array}{c}\text { Maxim } \\
\text { um }\end{array}$ & $\begin{array}{c}\text { Mea } \\
\mathrm{n}\end{array}$ & $\begin{array}{c}\text { Stan } \\
\text { dar } \\
\text { Devi } \\
\text { asi }\end{array}$ \\
\hline $\begin{array}{c}\text { Prete } \\
\text { st }\end{array}$ & 10,00 & 22,00 & $\begin{array}{c}15,46 \\
15\end{array}$ & $\begin{array}{c}3,733 \\
08\end{array}$ \\
\hline $\begin{array}{c}\text { Poste } \\
\text { st }\end{array}$ & 17,00 & 22,00 & $\begin{array}{c}10,00 \\
00\end{array}$ & $\begin{array}{c}1,779 \\
51\end{array}$ \\
\hline
\end{tabular}

Berdasarkan tabel 1, dapat ditunjukkan nilai terkecil, nilai terbesar, rata-rata, dan simpangan baku dari hasil evaluasi.pelatihan materi MS Word. Kelompok pretest memiliki nilai minimum (yang menjawab benar) sebesar 10; nilai maksimum (yang menjawab benar) sebesar 22, rata-rata (yang menjawab benar) sebesar 15.4615 dan simpangan baku sebesar 3.73308 dan kelompok postest memiliki nilai minimum (yang menjawab benar) sebesar 17; nilai maksimum (peserta menjawab benar) sebesar 22, rata-rata (peserta menjawab benar) sebesar 19 dan simpangan baku sebesar 1.77951 .

Tabel 2 Deskriptif Data Pelatihan MS Excel

\begin{tabular}{|c|c|c|c|c|}
\hline $\begin{array}{c}\text { Varia } \\
\text { bel }\end{array}$ & $\begin{array}{c}\text { Minim } \\
\text { um }\end{array}$ & $\begin{array}{c}\text { Maxim } \\
\text { um }\end{array}$ & $\begin{array}{c}\text { Me } \\
\text { an }\end{array}$ & $\begin{array}{c}\text { Stand } \\
\text { ar } \\
\text { Devi } \\
\text { asi }\end{array}$ \\
\hline $\begin{array}{c}\text { Pretes } \\
\text { t }\end{array}$ & 7 & 15 & $\begin{array}{c}10, \\
71\end{array}$ & 1,848 \\
\hline $\begin{array}{c}\text { Postes } \\
\text { t }\end{array}$ & 12 & 16 & $\begin{array}{c}14, \\
24\end{array}$ & 1,221 \\
\hline
\end{tabular}

Berdasarkan Tabel 2, dapat ditunjukkan deskriptif dari hasil evaluasi MS Excel. Kelompok pretest memiliki nilai minimum (yang menjawab benar) sebesar 7 ; nilai maksimum (yang menjawab benar) sebesar 15, rata-rata (yang menjawab benar) sebesar 10.71 dan simpangan baku sebesar 1.85 dan kelompok postest memiliki nilai minimum (yang menjawab benar) sebesar 12 ; nilai maksimum (yang menjawab benar) sebesar 16, rata-rata (yang menjawab benar) sebesar 14.24 dan simpangan baku sebesar 1.22.

Tabel 3 Deskriptif Data Pelatihan MS Excel

\begin{tabular}{|c|c|c|c|c|}
\hline $\begin{array}{l}\text { Varia } \\
\text { bel }\end{array}$ & $\begin{array}{l}\text { Mini } \\
\text { mum }\end{array}$ & $\begin{array}{l}\text { Maxi } \\
\text { mum }\end{array}$ & $\begin{array}{c}\text { Mea } \\
\mathrm{n}\end{array}$ & $\begin{array}{l}\text { Standar } \\
\text { Deviasi }\end{array}$ \\
\hline $\begin{array}{c}\text { Prete } \\
\text { st }\end{array}$ & 20,01 & 80,04 & $\begin{array}{l}53,6 \\
463 \\
\end{array}$ & $\begin{array}{c}17,644 \\
79 \\
\end{array}$ \\
\hline $\begin{array}{l}\text { Poste } \\
\text { st }\end{array}$ & 40,02 & 86,71 & $\begin{array}{l}68,0 \\
896\end{array}$ & $\begin{array}{c}14,188 \\
8050\end{array}$ \\
\hline
\end{tabular}

Berdasarkan tabel 4.3, dapat ditunjukkan deskriptif data nilai pelatihan. MS Power Point. Kelompok pretest memiliki nilai minimum (yang menjawab benar) sebesar 20.01; nilai maksimum (yang menjawab benar) sebesar 80.04, rata-rata (yang menjawab benar) sebesar 53.6463 dan simpangan baku sebesar 17.64478 dan kelompok postest memiliki nilai minimum (yang menjawab benar) sebesar 40.02; nilai maksimum (yang menjawab benar) sebesar 86.71, rata-rata (yang menjawab benar) sebesar 68.6089 dan simpangan baku sebesar 14.18050.

\section{Perbandingan Antara Kelompok Pretest dan Kelompok Postest Uji Normalitas}

Untuk menguji normalitas digunakan metode KolmogorovSmirnov. Berdasarkan analisis diperoleh nilai P-value sebesar 0.711 
DIFUSI

Volume 2, No.1 Januari 2019

untuk analisis data awal (pretest) dan sebesar 0.313 untuk analisis data akhir (posttest). Nilai pretest dan posttest masing-masing lebih besar dari nilai 0,05 (P-value), sehingga dapat disumpulkan bahwa asumsi kenormalan dipenuhi.

Tabel 4 Uji Normalitas Data Kelompok Pretes dan Kelompok Prostest

\begin{tabular}{|c|c|c|}
\hline $\begin{array}{c}\text { Kolmogorof - } \\
\text { Smirnov }\end{array}$ & Pre Test & Post Test \\
\hline $\begin{array}{c}\text { Asym-Sig .(2- } \\
\text { tailed) }\end{array}$ & 0,711 & 0,962 \\
\hline
\end{tabular}

\section{Uji Homogenitas}

Uji homogenitas dilakukan untuk mengetahui apakah data pada setiap kelompok hasil evaluasi untuk perbandingan memiliki keragaman yang sama. Sehingga dapat disimpulkan bahwa perbedaan yang terjadi dalam hipotesis berasal dari perbedaan antara kelompok, bukan berasal dari perbedaan di dalam kelompok. Berikut disajikan secara lengkap perhitungan hasil uji homogenitas data kelompok pretest dengan data kelompok postest.

Tabel 5 Uji Homogenitas Data Kelompok Pretest dan Postest

\begin{tabular}{|c|c|}
\hline Lavene Statistic & Sig \\
\hline 1,496 & 0,22 \\
\hline
\end{tabular}

Berdasarkan analisis diperoleh nilai probabilitas sebesar 0.228. Nilai tersebut lebih besar dari pada 0,05 sehingga dapat disimpulkan bahwa terima Ho, artinya data kelompok pretest dengan kelompok postest memiliki keragaman yang sama (homogen).

Berdasarkan tabel-tabel di atas dapat ditunjukkan bahwa asumsi parametrik dipenuhi. Oleh sebab itu pengujian akan dilakukan menggunakan metode parametrik, dalam hal ini menggunakan paired t-test (sampel berpasangan).

\section{Uji Paired-t-test}

Uji Paired-t-test adalah salah satu pengujian hipotesis dimana data yang berpasangan dan memenuhi asumsi kenormalan.

Rumusan hipotesis:

$H O$ : kelompok pretest dan kelompok postest tidak mempunyai perbedaan yang signifikan;

H1 : kelompok pretest dan postest mempunyai perbedaan yang signifikan.. $\alpha: 5 \%$

Kriteria uji:

Jika $p$-value $<\alpha$ maka tolak $H o$

$\mathrm{J} \quad p$-value $>\alpha$ maka terima $\mathrm{Ho}$

Berdasarkan analisis SPSS diperoleh output sebagai berikut : 
DIFUSI

Volume 2, No.1 Januari 2019

Tabel 6 Uji Beda Rata-rata Kelompok Pretest dan Kelompok Postest Pelatihan MS Word

Paired Samples Test

\begin{tabular}{|c|c|c|c|c|c|c|c|c|c|}
\hline & & \multicolumn{5}{|c|}{ Paired Diff erences } & \multirow[b]{3}{*}{$t$} & \multirow[b]{3}{*}{$\mathrm{df}$} & \multirow[b]{3}{*}{ Sig. (2-tailed) } \\
\hline & & \multirow[b]{2}{*}{ Mean } & \multirow[b]{2}{*}{ Std. Deviation } & \multirow{2}{*}{$\begin{array}{l}\text { Std. Error } \\
\text { Mean }\end{array}$} & \multicolumn{2}{|c|}{$\begin{array}{c}95 \% \text { Confidence } \\
\text { Interv al of the } \\
\text { Dif f erence }\end{array}$} & & & \\
\hline & & & & & Lower & Upper & & & \\
\hline $\begin{array}{l}\text { Pair } \\
1\end{array}$ & $\begin{array}{l}\text { Pretes_word - } \\
\text { Postes_word }\end{array}$ & $-3,53846$ & 3,09880 & ,85945 & $-5,41105$ & $-1,66588$ & $-4,117$ & 12 & ,001 \\
\hline
\end{tabular}

Tabel 7 Uji Beda Rata-rata Kelompok Pretest dan Kelompok Postest Pelatihan MS Excel

Paired Samples Test

\begin{tabular}{|c|c|c|c|c|c|c|c|c|}
\hline & \multicolumn{5}{|c|}{ Paired Diff erences } & \multirow[b]{3}{*}{$\mathrm{t}$} & \multirow[b]{3}{*}{$\mathrm{df}$} & \multirow[b]{3}{*}{ Sig. (2-tailed) } \\
\hline & \multirow[b]{2}{*}{ Mean } & \multirow[b]{2}{*}{ Std. Dev iation } & \multirow{2}{*}{$\begin{array}{c}\text { Std. Error } \\
\text { Mean }\end{array}$} & \multicolumn{2}{|c|}{$\begin{array}{l}95 \% \text { Confidence } \\
\text { Interv al of the } \\
\text { Difference }\end{array}$} & & & \\
\hline & & & & Lower & Upper & & & \\
\hline Pair 1 Pretest - Postest & -3.524 & 1.750 & .382 & -4.320 & -2.727 & -9.228 & 20 & .000 \\
\hline
\end{tabular}

Tabel 8 Uji Beda Rata-rata Kelompok Pretest dan Kelompok Postest Pelatihan MS Power Point

Paired Samples Test

\begin{tabular}{|c|c|c|c|c|c|c|c|c|}
\hline & \multicolumn{5}{|c|}{ Paired Diff erences } & \multirow[b]{3}{*}{$t$} & \multirow[b]{3}{*}{ df } & \multirow[b]{3}{*}{ Sig. (2-tailed) } \\
\hline & \multirow[b]{2}{*}{ Mean } & \multirow[b]{2}{*}{ Std. Deviation } & \multirow{2}{*}{$\begin{array}{l}\text { Std. Error } \\
\text { Mean }\end{array}$} & \multicolumn{2}{|c|}{$\begin{array}{c}95 \% \text { Confidence } \\
\text { Interval of the } \\
\text { Difference }\end{array}$} & & & \\
\hline & & & & Lower & Upper & & & \\
\hline Pair 1 Pretes_PP - Postes_PP & $-14,44333$ & 11,91091 & 2,43130 & $-19,47287$ & $-9,41380$ & $-5,941$ & 23 &, 000 \\
\hline
\end{tabular}

Dari tabel 8 diperoleh nilai p-value berturut-turut untuk pelatihan MS Excel, MS Power Point, dan MS Word sebesar 0.0000; 0000; dan 0.001 . Nilai masing-masing di atas disetarakan dengan alpha, masing-masing nilai $\mathrm{p}$ value tersebut lebih kecil $(0,000<0,05)$ maka H0 ditolak. Artinya, terdapat perbedaan yang signifikan antara kelompok kemampuan awal (pretest) dan kelompok kemampuan akhir (postest).

\section{Pengolahan Data Kuesioner}

Angket atau Kuesioner evaluasi pelatihan yang mengandung pertanyaan dan pernyataan terbuka disi oleh peserta. Jawaban peserta pelatihan dijadikan dasar masukan dan pertimbangan kebijakan dalam pelaksanakan pelatihan berikutnya. 


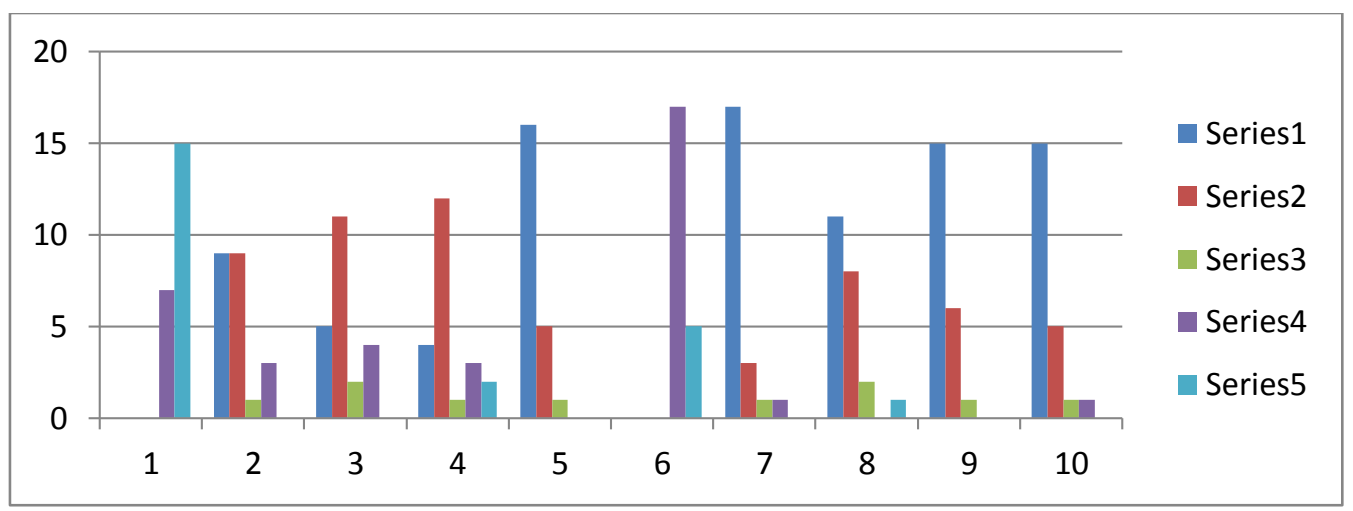

Gambar 4 Diagram Hasil Tanggapan Kuesioner Mitra

Angket atau Kuesioner evaluasi pelatihan yang mengandung pertanyaan dan pernyataan terbuka disi oleh peserta. Jawaban peserta pelatihan dijadikan dasar masukan dan pertimbangan kebijakan dalam pelaksanakan pelatihan berikutnya.

Berdasarkan Gambar 4 dapat diperlihatkan bahwa:

Pernyataan 1, sebesar $68.2 \%$ mengatakan sangat setuju dengan materi yang diikuti cukup menarik dan sesuai dengan Sekitar $31.8 \%$ yang menjawab setuju dengan pernyataan ini.

Pernyataan 2, sebesar $40.9 \%$ responden menjawab tidak setuju dan kurang setuju terhadap pernyataan bahwa materi pelatihan sangat banyak dan sulit dipahami. Akan tetapi $13.6 \%$ mengatakan setuju bahwa materi pelatihan sangat banyak dan sulit dipahami.

Pernyataan 3, sebesar 50\% mengatakan bahwa penjelasan materi yang diberikan terlalu cepat sehingga sulit diikuti oleh peserta.

Pernyataan 4, sebesar $54.5 \%$ responden menyatakan kurang setuju dengan pernyataan bahwa waktu penyampaian materi terlalu singkat sehingga semua materi tidak dibahas semua. Dan sebesar $18.2 \%$ responden menyatakan tidak setuju.

Pernyataan 5, sebesar 54.5\% responden mengatakan kurang setuju terhadap pernyataan pemateri kurang menguasai materi sehingga terlalu monoton dan kurang menarik.

Pernyataan 6, sebesar $72.7 \%$ responden mengatakan setuju dengan pelaksanaan tepat waktu dan tidak terlambat. Dan sebesar $22.7 \%$ menyatakan sangat setuju dengan pernyataan ini.

Pernyataan 7, sebesar $72.7 \%$ responden mengatakan tidak setuju bahwa jumlah peserta terlalu banyak, tidak dibatasi sehingga suasana menjadi rame.

Pernyataan 8, sebesar 77,3 \% mengatakan tidak setuju bahwa ruang pelatihan terlalu sempit dan kurang nyaman.

Pernyataan 9, sebesar 50\% responden mengatakan tidak setuju terhadap sistem kerja panitia kurang terorganisir sehingga terkesan kurang terkoordinir. Dan sebesar 36.4\% menyatakan kurang setuju terhadap pernyataan tersebut.

Pernyataan 10, sebesar $68.2 \%$ responden menyatakan tidak setuju terhadap pernyataan bahwa sarana 
DIFUSI

Volume 2, No.1 Januari 2019

pelatihan (software) kurang memadai sehingga mengganggu kelancaran pelatihan. Dan sebesar 27,3\% Adapun rekapitulasi dari jawaban responden secara rata-rata disajikan menyatakan kurang setuju terhadap dalam tabel 9.

pernyataan tersebut.

Tabel 9 Rekapitulasi Hasil Kuesioner pada Pelatihan Pembelajaran Berbantuan Komputer

\begin{tabular}{|c|l|c|}
\hline No & Pernyataan Kuesioner & $\begin{array}{c}\text { Rata-rata Pendapat } \\
\text { Responden }\end{array}$ \\
\hline 1 & $\begin{array}{l}\text { Selama mengikuti pelatihan ini, materi yang diberikan cukup } \\
\text { menarik sesuai dengan kebutuhan saya saat ini. }\end{array}$ & Sangat Setuju \\
\hline 2 & Materi pelatihan sangat banyak dan sulit dimengerti & Kurang Setuju \\
\hline 3 & $\begin{array}{l}\text { Penjelasan materi yang diberikan terlalu terburu-buru sehingga } \\
\text { saya sulit mengikutinya }\end{array}$ & Kurang Setuju \\
\hline 4 & $\begin{array}{l}\text { Waktu penyampaian materi sangat singkat sehingga semua materi } \\
\text { tidak selesai dibahas }\end{array}$ & Kurang Setuju \\
\hline 5 & $\begin{array}{l}\text { Pemateri sedikit menguasai materi sehingga terlalu monoton dan } \\
\text { kurang menarik }\end{array}$ & Tidak Setuju \\
\hline 6 & $\begin{array}{l}\text { Pelaksanaan tepat waktu dan tidak terlambat } \\
\text { menjadi rame } \\
7\end{array}$ & $\begin{array}{l}\text { Ruang pelatihan terlalu sempit dan kurang nyaman } \\
\text { terkoordinir }\end{array}$ \\
\hline 9 & $\begin{array}{l}\text { Sarana pelatihan atau keberdaan software kurang memadai } \\
\text { sehingga mengganggu kelancaran pelatihan }\end{array}$ & Turang Setuju \\
\hline
\end{tabular}

Hasil analisis pernyataan terbuka dari peserta pelatihan adalah :

1. Materi power point lebih banyak diberikan lagi, supaya para guru

2. Matematika dan fisika bisa mengajar lebih baik dengan penampilan power point yang lebih menarik lagi.

3. Peserta pelatihan meminta pelatihan berikutnya yang lebih menarik serta lebih mendetail.

4. Pelatihan hendaknya dilakukan pada saat libur panjang siswa.

5. Diharapkan tambahan waktu pelatihan agar para peserta pelatiahan lebih terampil, pemateri dan materinya sudah bagus, praktek langsung menggunakan komputer diharapkan lebih diperbanyak waktunya.

6. Pelatihan ini sangat bermanfaat dan membantu meningkatkan proses pembelajaran di kelas.

7. Kerjasama ini sebaiknya dijadikan sebagai agenda rutin tahunan untuk MGMP di Kabupaten Bandung.

\section{Rencana Tahapan Berikutnya}

Dengan telah dilaksanakan kegiatan pengabdian masyarakat berbentuk pelatihan pembelajaran berbantuan komputer bagi kelompok MGMP Matematika dan IPA Fisika SMP mitra tahun 2013, hasil pelatihan dapat diimplementasikan saat menjalankan tugas pengajaran sehari-hari, sehingga 
DIFUSI

Volume 2, No.1 Januari 2019

menjadi bagian dalam meningkatkan kualitas hasil belajar. Penerapan hasil pelatihan dapat dilaksanakan dalam jangka waktu yang panjang, sehingga dalam periode pengabdian mendatang, tahun 2014 kegiatan pengabdian dapat dilanjutkan dengan kegiatan berbentuk penelitian. Penelitian yang dimaksud di sini adalah sebagai tindak lanjut berupa pengamatan untuk mengevaluasi hasil kemampuan peserta dalam mengimplementasi hasil pelatihan pembelajaran berbantuan komputer. Peningkatan kemampuan pengelolaan pembelajaran berbantuan komputer akan dievaluasi dengan melibatkan guru, siswa, dan media pendukungnya melalui serangkaian kegiatan antara lain studi pendahuluan, mou kegiatan, penentuan sampel dan analisis data.

Hasil penelitian tahun 2014, akan menggambarkan keberhasilan atau tidaknya peranan pengabdian masyarakat yang dilaksanakan atas kerja sama UPPM Polban dengan mitra dalam meningkatkan kemampuan keterampilan penggunaan komputer dalam pembelajaran yang dilakukan.

\section{SIMPULAN DAN SARAN}

\section{Simpulan}

Simpulan yang diperoleh dari kegiatan pengabdian masyarakat yang dilakukan pada MGMP Matematika dan MGMP Fisika dari beberapa SMP Gugus 04 Kabupaten Bandung Jawa Barat adalah

1. Terdapat perbedaan pengetahuan awal pelatihan dan akhir pelatihan, dengan peningkatan kemampuan dengan rata-rata sebesar $27.59 \%$.

2. Terdapat perbedaan keterampilan dalam penggunaan komputer antara sebelum dilakukan pelatihan dan setelah pelatihan.

3. Perhatian dan atensi peserta dalam mengikuti pelatihan sangat bagus.

4. Peserta pelatihan sangat antuasias dengan program yang diberikan (dari jawaban hasil kuesioner yang diberikan)

\section{Saran}

1. Berdasarkan evaluasi kegiatan, dapat dilihat banyak diantara peserta yang masih awam dan kaku menggunakan Microsoft Office, khususnya dalam proses pembelajaran. Dengan demikian disarankan, perlu diadakan pelatihan MS Office kepada MGMP di gugus lain. Khususnya pada sekolahsekolah di pinggiran kota Bandung atau di daerah kabupaten (terpencil).

2. Implementasi hasil pelatihan dapat dilaksanakan dalam jangka waktu yang panjang, sehingga dalam periode pengabdian mendatang, tahun 2014 kegiatan pengabdian dapat dilanjutkan dengan kegiatan berbentuk penelitian. Penelitian yang dimaksud di sini adalah sebagai tindak lanjut berupa pengamatan untuk mengevaluasi hasil kemampuan peserta dalam mengimplementasi hasil pelatihan pembelajaran berbantuan komputer. Peningkatan kemampuan pengelolaan pembelajaran berbantuan komputer akan dievaluasi dengan melibatkan guru, siswa, dan media pendukungnya 
melalui serangkaian kegiatan antara lain studi pendahuluan, mou kegiatan, dan analisis data statistik. Hasil penelitian tersebut, dapat menggambarkan berhasil atau tidaknya kegiatan pengabdian masyarakat yang telah dilaksanakan atas kerja sama UPPM Polban dengan MGMP Matematika dan IPA Fisika SMP gugus 04 sebagai mitra.

\section{REFERENSI}

[1] Eggen, P.D \& Kauchak, D.P., (1988), Strategies for teacher: Teaching Content and Thinking Skill, Allyn and Bacon: Boston.

[2] Jiang, Z. (2008), Explorations and Reasoning in the Dynamic Geometry Environment. [Online]. Tersedia:

http://atcm.mathandtech.org/EP20 08/papers_full/2412008_15336.pd f. [25 Januari 2009]

[3] Kusumah, Y. S. (2008). Konsep, Pengembangan, dan Implementasi Komputer-Based Learning Dalam Peningkatan Kemampuan HighOrder Mathematical Thinking. Makalah disajikan dalam Pengukuhan Guru Besar Pendidikan Matematika FMIPA UPI Bandung.

[4] Muldiani, R. Fenny (2011). Media Pembelajaran Berbasis Animasi Komputer pada Mata Kuliah Fisika Terapan untuk program Studi Teknik Aeronautika Politeknik Negeri Bandung, Jurnal Sigma-Mu Vol. 3 No. 1, UP MKU POLBAN, h. 11-20.

[5] Sartika, dkk (2012), Pelatihan MS Office danSoftware Winplot Bagi
Guru Matematika SMP Se Kota Cimahi, Laporan Akhir Program Pengabdian Pada Masyarakat, Polban

[6] Syah, Muhibbin. (2000). Psikologi Pendidikan dengan Pendekatan Baru. Bandung: PT Remaja Rosdakarya.

[7] Suyitno A, Suhitio. (2000). Pengembangan Rancangan Mata Kuliah Matematika Berbasis Kegiatan Eksperimen Pada Program Studi Pendidikan Matematika (Suatu Alternatif Model Pembelajaran). Proceding Seminar Nasional Pengembangan Pendidikan MIPA di Era Globalisasi. Univetsitas Negeri Yogyakarta, 22-8-2000. 